\title{
Convocation Address - 2016
}

\section{Asha Singh Kanwar*}

(May 2016, Commonwealth of Learning)

Honorable Chancellor,

Distinguished members of the OUSL,

Graduands,

Parents and friends,

It is a special privilege to receive a DLitt (honoris causa) from the Open University of Sri Lanka, a pioneer in distance learning in Asia and I thank the Vice Chancellor, Professor Ariadurai, and the university community for this great honour.

Convocation is a very important milestone in the life of an institution and I am really pleased to be a part of this happy occasion. OUSL was established nearly four decades ago and during this time has provided opportunities to thousands of men and women who are very diverse in terms of age, income and social background, to gain qualifications ranging from certificates to diplomas, degrees and doctorates. If the student cannot reach the institution, the institution is reaching the student in remote rural locations through flexible need-based programmes.

Even though access to quality higher education is still a distant dream for many young people globally, the demand for tertiary qualifications continues to grow. Sri Lanka has a broad system of higher education institutions: 15 public universities, 14 public higher education institutes and more than 40 private institutions. Yet, the Age Participation Rates of the 18-24 year-olds in higher education is about $17 \%$, significantly lower than the OECD average of $40-50 \%$, which is required for sustainable economic development in any country. Sri Lanka is exploring various ways of increasing access to quality higher education to its citizens.

\footnotetext{
* Correspondence should be addressed to Prof. Asha Singh Kanwar, President \& Chief Executive Officer of the Commonwealth of Learning, (Email: akanwar@col.org)
} 
Open and Distance Learning or ODL is considered a viable option as it can enhance access, raise standards and reduce costs. UGC is supporting public universities to offer more distance and online provision. The National Online Distance Education Service or NODES access centres are another way of strengthening ODL infrastructure in the country. My organisation, the Commonwealth of Learning or COL, has supported the development of a draft policy on ODL for Sri Lanka which will create an enabling environment for distance and online learning to flourish and for more citizens to access quality higher education at affordable costs.

When Heads of Government decided to set up the organization, the Commonwealth of Learning in 1987, they saw this as an imaginative response to strengthening higher education in the developing world by making use of the potential of open, distance and technology enhanced education. Over the past three decades, we have witnessed an interesting trend. In 1988, there were only 10 open universities in the Commonwealth, of which three were in Canada and one in the UK. Twenty eight years later, that number has tripled. In Canada, the number has reduced from three to just one existing open university in the country. The growth has happened mainly in developing countries. India alone has 17 open universities and the five Open Universities in Commonwealth Africa will soon be joined by open universities in Botswana and Kenya.

Research shows that there is 'no significant difference' between distance and traditional classroom instruction in terms of learning outcomes; yet there is a lingering perception, especially in the developing world, that distance education is not as effective or adequate as campus-based learning. How do we address this gap in understanding and perception? It is interesting that the perceptions about the effectiveness of distance education in the developed countries are quite different from those in the developing countries. For instance, the Open University of the UK ranks regularly in the top five universities in the UK for student satisfaction and quality. Similarly in Canada, there is no distinction made between a campus or distance learning 
qualification. Institutions in the developing world need to do much more to raise the profile and quality of open and distance learning.

However, in my view, the students who succeed from a distance learning institution, as you have done, are any employer's dream. Instead of studying full time in a campus university, you have often balanced the requirements of study with your family responsibilities and job requirements. You are multi-taskers who can do several things efficiently. It is because of your motivation, discipline and commitment that you are sitting here today to receive your hard-won qualifications.

I did my Master Degree studying at a distance since I was married at the age of eighteen. I come from a mountain community in India, where marriage rather than education was the ultimate goal for girls. But I wanted to study like my other friends who were going on to pursue further education in the big cities. I couldn't go to the big cities but I could still study at a distance. So distance education provided me with an opportunity I would otherwise not have had. In those days, getting a degree was quite enough and it opened many doors for me.

Today the world has changed and knowledge is multiplying at a rapid pace. What we learnt two or three decades ago is just not enough even for survival, let alone for success, in a highly competitive global market. Research indicates that you could have two to four careers in a lifetime. So if you enter the world of work, you will still need to continue to learn, unlearn and re-learn many different things during the course of your life. In short you need to be lifelong learners if you wish to succeed.

Unemployment is a global challenge, particularly youth unemployment which is $12.6 \%$ globally. Here in Sri Lanka, $20 \%$ of the young people are unemployed. And many countries face similar challenges. There is a great deal of emphasis on skills development in many Commonwealth countries. What are the skills required for employability? A study interviewed employers in five cities in South Asia: New Delhi, Mumbai, Bhopal; Lahore and Dhaka. Two clear themes emerged from the employer interviews in the three 
countries. The first is the importance of skills such as leadership, communication, honesty/ethics, teamwork and flexibility. The second is the importance of being able to learn and the need for critical thinking and analytical skills (Burnett, p. 9).

One of the fundamental problems in our countries is the mismatch between education and employment. Are we teaching our students the skills they need for gainful employment? Experts warn that our education systems are churning out a workforce without the requisite skills for the new economy.

Linda Gratton in her book The Shift--The Future of Work is already here talks about five major forces that will fundamentally change the way we work. The five forces are: one, the force of technology; two, the force of globalization; three, the force of demography and longevity; four, the force of society and five, the force of energy resources.

How will we face these five forces? According to Gratton we need to make three shifts. The first shift involves making a move from being a shallow generalist to a serial master. What does this mean? Today we cannot succeed by simply being a 'generalist' who knows a little bit about this and that. We need to become 'serial masters' who have in-depth knowledge and competencies in a number of domains. In the past we could be experts in one field and that was quite enough. But today we may need to be experts in several areas. I started out as a professor of literature, moved into the field of education and now work in international development. With so much talent to choose from, what unique skill do we have to stand out? What role does our educational system have in helping us make this shift?

The second shift refers to making a transition from being an 'isolated competitor' to an 'innovative connector'. Instead of working alone we need to work collaboratively with others. This should not be difficult since the majority of the global population of 7 billion is connected in some way or another through technology. Traditionally, success at work was often attributed to personal drive and ambition. Now, it is becoming increasingly clear that we 
need to have a combination of two skills - expertise in a chosen field and a strong network.

Geoff Colvin's recent book Humans are Underrated says that the high achievers in the twenty-first century will be 'relationship workers' as opposed to the 'knowledge workers' of the twentieth century. Robots will perform most tasks better than human beings, but it is humans who have social skills and empathy, can solve complex problems and are creative. How do we nurture these skills?

The third shift is from being a voracious consumer to impassioned producer. This includes a transition towards work that is more meaningful, where you can 'make things' and become an entrepreneur. It is more about moving away from a nation of job seekers to a nation of enterprising employees and employers. But that requires hard work.

Malcolm Gladwell gives an interesting recipe for how to become a world class expert in any field of activity - it is the 10,000 hour practice rule. For example, Bill Gates got the opportunity to do computer programming when still in Grade 8. He spent about 2030 hours on the computer every week during the night and on weekends and he exceeded the 10,000 hour mark in about seven years. As Henry Ford puts it 'Genius is seldom recognized for what it is a great capacity for hard work.'

I am sure OUSL has equipped you with a robust capacity for hard work and discipline. OUSL has been constantly working on improving the quality of its provision for over a decade and COL has accompanied it on this journey. OUSL has gone through a successful completion of the COL Review and Improvement Assessment which will further enhance the 'culture of quality' within the institution. The Commonwealth of Learning values its collaboration with OUSL, and you will be pleased to know that a former OUSL staff member Dr. Ishan Abeywardena, now works for COL. We will continue this partnership as the University adopts new technologies and approaches to provide higher education relevant for the needs of the twenty-first century. 
In closing, let me extend my warm greetings and congratulations to all of you, my fellow graduates. As you set out on the next steps of your journey, and as you cross many more milestones that mark your achievements, I am sure you will proudly recall the value of the opportunities that OUSL gave you, and how it empowered you for success. Thank you.

\section{References:}

Gratton, Lynda (2011). The Shift: The Future of Work is Already Here. London. Collins.

Burnett, Nicholas (2012). 'Skills for Employability in Africa and Asia'; Results for Development Institute.

Gladwell, Malcolm. (2008). Outliers.

Geoff Colvin (2015). Humans are Underrated. New York. Portfolio/Penguin. 